\title{
Insights into Interdisciplinary Approaches for Bioremediation of Organic Pollutants: Innovations, Challenges and Perspectives
}

\author{
Bishwambhar Mishra $^{1}$ - Sunita Varjani ${ }^{2}$ - Ipshita Pradhan $^{3} \cdot$ Nakkeeran Ekambaram $^{4}$. \\ Jose A. Teixeira ${ }^{5} \cdot$ Huu Hao $\mathrm{Ngo}^{6} \cdot$ Wenshan Guo ${ }^{6}$
}

Received: 23 December 2019/Revised: 5 June 2020/ Accepted: 3 July 2020

(C) The National Academy of Sciences, India 2020

\begin{abstract}
Modern industrialization has originated a tremendous industrial growth. Discharge of industrial effluent is a critical threat to a safe environment. Removal of various pollutants from industrial wastewater is obligatory for controlling environmental pollution. Bioremediation using biotechnological interventions has attracted greater attention among the researchers in the field of control and abatement of environmental pollution. This review is aimed to introduce methods for bioremediation on the removal of organic pollutants from industrial wastewater that have been discussed, and the kinetic models that are related to it have been introduced. In addition, biotechnological interventions on bioremediation of pollutants have been discussed fingerprinting of microbial sp. present at polluted sites. Microbial electrochemical technologies such as a green technology for the removal of
\end{abstract}

Sunita Varjani

drsvs18@gmail.com

1 Department of Biotechnology, Chaitanya Bharathi Institute of Technology, Hyderabad 500075, India

2 Gujarat Pollution Control Board, Gandhinagar, Gujarat 382010 , India

3 Department of Biotechnology, Sreenidhi Institute of Science and Technology, Hyderabad 501301, India

4 Department of Biotechnology, Sri Venkateswara College of Engineering, Sriperumbudur Tk 602117, India

5 CEB - Centre of Biological Engineering, University of Minho, 4710057 Braga, Portugal

6 Centre for Technology in Water and Wastewater, School of Civil and Environmental Engineering, University of Technology Sydney, Sydney, NSW 2007, Australia pollutants from industrial effluents and simultaneous resource recovery from industrial waste have been discussed to generate up-to-date scientific literature. This review also provides detailed knowledge gaps, challenges and research perspectives related to the topic.

Keywords Effluents - Persistent organic pollutants · Biodegradation - Resource recovery .

Microbial electrochemical technologies

\section{Introduction}

The rapid rise in industrialization and urbanization has led to major land, water and air pollution. As well as being a major international challenge of the twenty-first century, soil pollution has been recognized as a significant concern. Soil remediation and management are very critical for the sustainable future in the development of food, fodder, fuel and medicinal products. The contamination caused by heavy metals is a major problem for the environment. They have long existed in the habitats and have a detrimental impact on human health, soil quality, plant growth and development. Heavy metal contamination occurs mostly in developing countries because untreated waste products and residues are frequently released into open environments. At present, different technologies (absorption, biological treatment, ion exchange process, oxidative decoloration) have been developed for the treatment of these groups of pollutants [1]. Broadly these methodologies have been divided into physical, chemical and biological as illustrated in Fig. 1. Many industries such as the pharmaceutical industry, leather industry, and pulp and paper industry contribute to modern living standards. However, increasing chemical consumption has led to an increase in 
Fig. 1 Interdisciplinary approaches to treat pollutants

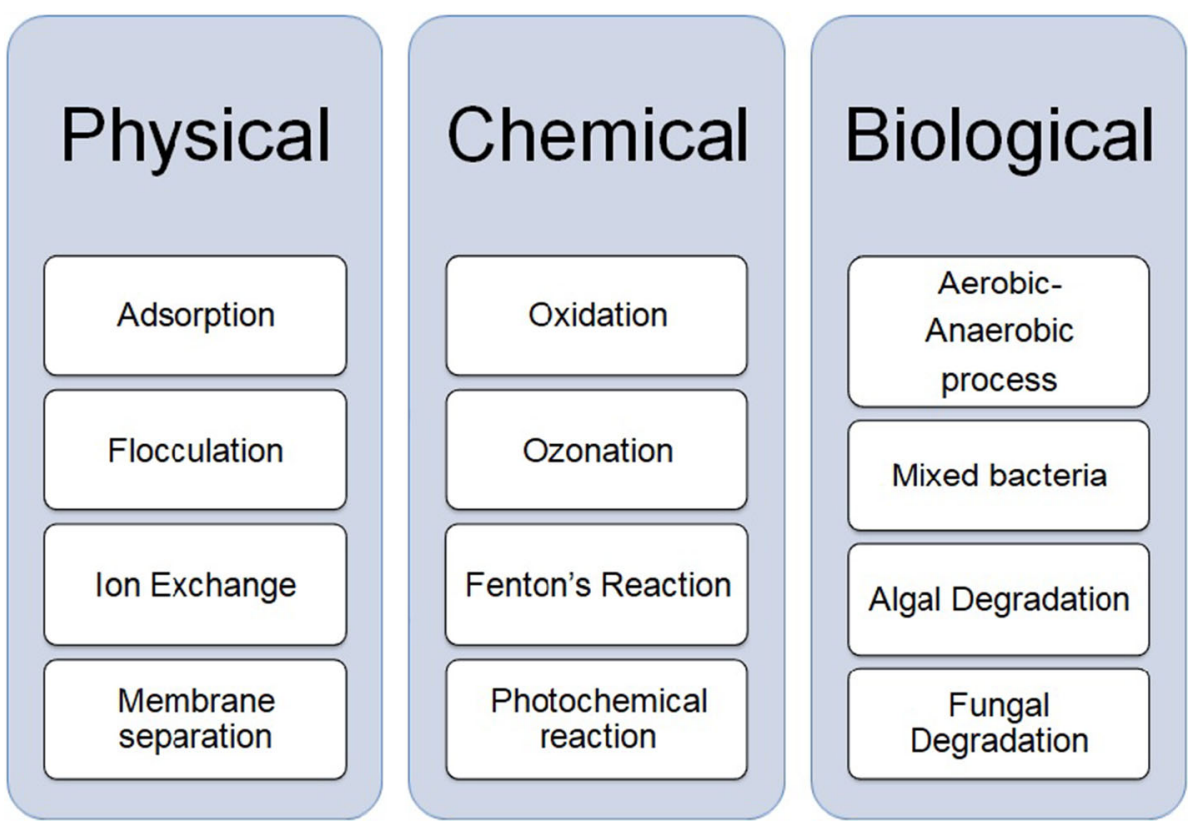

environmental pollution. Pollution sources can be divided into natural and anthropogenic sources. Natural sources include volcanic activity, and pesticides, heavy metals, chemical substances and organic contaminants are anthropogenic sources. The toxicological phenomenon triggered by organic pollutants is extremely damaging from the above-mentioned anthropogenic sources [2].

In this present review, the characteristics and types of organic pollutants are explored with special reference to industrial waste, and their impacts on the ecosystem and the modern approach to treat those pollutants have been discussed. Additionally, the current literature on modern biotechnological approaches and microbial electrochemical technologies and its efficiency in organic pollutant removal is also discussed. Finally, the knowledge gap, challenges and perspectives of this technology are presented.

\section{Organic Pollutants from Industrial Effluents}

Organic pollutants are an important part of contaminants in the ecosystem and have posed a severe threat to the environment and human health. Industrial pollution and the heavy metal-polluted agricultural soil zone have been continuing to expand. Soil pollution has transformed from a single pollution site to another site, and by moving and accumulating soil-plant systems, it has seriously threatened the world's increase in agricultural product quality, crop yields, security and human health. Scientists used different strategies to eradicate industrial pollutants such as biodegradation, filtering, photolysis, adsorption and hydrolysis.

\section{Antibiotics}

The development of antibiotics has transformative effects on human medicine. In spite of its wide range of advantages and applications, the pharmaceutical sewage containing antibiotics in the manufacturing plant slowly affect the living environment of people. It continues to present in the ecosystem in the process of bioaccumulation and transformation. Consequently, antibiotics are recently recognized as an emerging pollutant to the environment. Scientists have also concerned with the elimination of antibiotics, through its adsorption with the applications of biochar. For example, several researchers used modified biochar as raw material with peanut shells and added $\mathrm{Cu}\left(\mathrm{NO}_{3}\right)_{2}$ for the removal of doxycycline hydrochloride through adsorption. It was also found that the removal of doxycycline hydrochloride with the application of copper nitrate-modified biochar is faster than that of raw biochar. Similarly, tetracycline was eliminated with the application of iron and zinc mixed biochar (Fe/Zn biochar) [3].

\section{Dyes}

With the enormous growth of textile industries, the effluents generated in the form of dyes and other chemicals have become a major source of pollution in the environment. It was estimated that more than 100,000 forms of chemical pigments are utilized in textile industries for dyeing purposes. Those chemicals are discharged into the water, making it more polluted. Very low levels of dye in water are very dangerous. There are many ways that dyes can be removed from wastewater. Adsorption technology 
has strong efficiency prospects relative to other technologies in these methods [4]. Applications of dyes add a lot of excitement and vitality to our lives. However, most of them are found to be possessed persistent chemical properties and complex structures having a significant negative impact on human health and the environment.

\section{Oils}

In the current situation, the industry's rapid development has resulted in severe environmental pollution, a very serious part of which is oil emissions. Petroleum is a complex mixture of hydrocarbon chemicals that can last in the ecosystem for a considerable period, resulting in significant long-term pollution. One of the main contaminants of the atmosphere is oil pollution. Oil emissions will be caused during the process of drilling, mining, transportation and processing. The effect of oil emissions on crustal microorganisms is high. Petroleum pumped into the soil will influence the soil's permeability and irrigation water will gradually enter into the groundwater surface with precipitation, thereby contaminating the groundwater, reducing groundwater use. Therefore, the interest of people should be drawn. Oil spills in the ocean is a global problem and challenge due to the slow current movement and poor ocean self-purification capacity [5].

Besides causing severe long-term destruction and damage to the oceanic ecosystem, frequent oil spills are also responsible for the loss of valuable resources. Post-contamination treatment is also very essential to avoid oil pollution in the ecosystem.

\section{Pesticides}

Pesticides are agricultural development components as the main method for regulating agricultural and pest infections. Widespread use of pesticides may improve agricultural productivity and the economic advantages of agricultural production. While in many nations' organochlorine pesticides have been banned, residues of this pesticide in the soil are still high in some areas. Increased use of pesticides can result in some extent of pollution of soil and water. This can produce toxic effects on nontarget species, disrupt the ecological balance and pose a risk to human health. The use of pesticides has several advantages for agricultural output and human life, but the environmental issues it creates have also become increasingly evident [6].

\section{Persistent Organic Pollutants (POPs)}

Persistent organic pollutants (POPs) are exceptionally difficult to biodegrade in the environment and will remain for a number of years in the environment, soil and food chain.
POPs have gradually become one of the most critical compound pollutants in the world due to their long-term bioavailability. Particular attention is paid to polycyclic aromatic hydrocarbons, polybrominated diphenyl ethers, organochlorine pesticides and halo hydrocarbons. Because of their low biodegradability, organic contaminants remain in the atmosphere for many years or perhaps centuries. The accumulation of these pollutants can cause ecosystem damage that is not reversible. Because of its acute toxicity and high demand for oxygen, these contaminants can cause enormous disruption and deteriorate for the aquatic ecological system. Some of the organic pollutants such as benzofurans and dioxins are highly toxic and persistent in the ecosystem [7].

\section{Methods Used for the Treatment of Industrial Effluents}

\section{Oxidative Decoloration}

Oxidative decoloration is a very simple method for the decoloration of the industrial effluents. Here, the industrial effluents are treated with the oxidizing agents through the aromatic ring cleavage process. Different methodologies like electrochemical destruction, ozonation and treatment of Fenton's reagent have been implemented in order to remove the color from the effluents through the oxidation. In some cases, hydrogen peroxide $\left(\mathrm{H}_{2} \mathrm{O}_{2}\right)$ is also used for the oxidative decoloration of water $[8,9]$. The main obstacle for these methods is the formation of piles of sludge and other unwanted substances deposited successively $[10,11]$. Various approaches to utilize oxidizing materials and their efficiency to treat the various groups of pollutants are summarized in Table 1.

\section{Adsorption}

The physical interaction between the pollutants and the sorbent facilitates its separation from the effluents. Generally, the adsorption process targets the dyes and coloring agents present in the industrial effluents. The major advantage of adsorption is that there are not any harmful chemicals formed during the treatment. Various substances like activated carbon and silica gel zeolites have been used commonly as adsorbents to remove the pollutants [12]. Adsorption is the best method to clean up the pollutants through physicochemical interactions because of its simplicity economic feasibility nature. In addition to this, the adsorbents are not sensitive to toxic products and very easy to operate [13]. The adsorbing substances (activated charcoal, alumina, clay, zeolites and silica gel) possess high surface area per unit weight. The efficiency of the pollutant 
Table 1 Selected pollutants and their removal through the process of oxidation

\begin{tabular}{|c|c|c|c|c|}
\hline $\begin{array}{l}\text { Sr. } \\
\text { no. }\end{array}$ & $\begin{array}{l}\text { Target } \\
\text { pollutant }\end{array}$ & Oxidizing agent & Efficiency & References \\
\hline 1 & $\begin{array}{l}\text { Acid orange } 7 \\
\quad(\mathrm{AO} 7)\end{array}$ & Photo-Fenton heterogeneous catalyst (Fe-TS-1 zeolite) & $99.9 \%$ removal in 40 min was reported & [4] \\
\hline 2 & Methylene blue & $\mathrm{Fe}_{3} \mathrm{O}_{4} / \mathrm{TiO}_{2} /$ reduced graphene oxide & $\begin{array}{l}\text { The total efficiency of removal reached } 99 \% \text { after } \\
60 \mathrm{~min}\end{array}$ & {$[8]$} \\
\hline 3 & Methylene blue & Carbon-coated titanium electrode & $\begin{array}{l}\text { Efficiency of decolorization for C-Ti electrode } \\
\text { was } 100 \% \text { in } 20 \mathrm{~min}\end{array}$ & [9] \\
\hline 4 & $\begin{array}{l}\text { Acid orange II } \\
\text { (AO7) }\end{array}$ & Organic acids (lactic acid and acetic acid) & $\begin{array}{l}\text { Efficiency of decolorization was } 69.0 \% \text { within } \\
4 \mathrm{~min}\end{array}$ & {$[10]$} \\
\hline 5 & Methyl orange & $\begin{array}{l}\text { Hydrothermal oxidation with a flow-type reactor packed } \\
\text { with } \mathrm{MnO}_{2} \text { catalyst }\end{array}$ & $95 \%$ removal was reported & [11] \\
\hline
\end{tabular}

removal depends upon various factors like $\mathrm{pH}$ of the pollutants, the temperature of operation, contact time with the pollutants, nature and surface of the adsorbent [14, 15]. Various approaches to apply adsorbing materials and their efficiency to treat the various groups of pollutants are summarized in Table 2.

\section{Ion Exchange}

The ion exchange technique applies to only certain kinds of colorants present in the pollutants. Generally, resins are used as the ion exchanger to treat the industrial effluents. When the ion exchange resin has been saturated with the pollutants, the efficiency of the process decreased [16-20]. Various approaches to utilize different groups of ion exchangers and their efficiency to treat the various groups of pollutants are listed in Table 3 .

\section{Membrane Separation}

Membrane separation is mainly meant for the treatment of wastewater coming from the industrial effluents. The pore size of the membranes is the critical parameter to separate the dye and other pollutants present in the aqueous solution [21]. High pressure is applied through the membrane for the membrane filtration process. The major drawback is that clogging of the membrane may occur during the process and it is very difficult to handle the large volume of industrial effluents [22-25]. Various approaches to use different kinds of membranes used and their efficiency to treat the various groups of pollutants are depicted in Table 4 .

\section{Biotechnological Approaches/Interventions}

Various key enzymes from potentially different microorganisms have been identified which break down diverse groups of pollutants through biodegradation. Many microorganisms have the plasmids and catabolic genes that are responsible for catalyzing the process of biodegradation for major pollutants. Different genes are identified in similar microorganisms having potential to degrade different groups of contaminants. They provided the

Table 2 Role of adsorption in the removal of pollutants

\begin{tabular}{|c|c|c|c|c|}
\hline $\begin{array}{l}\text { Sr. } \\
\text { no. }\end{array}$ & Target pollutant & Adsorbing material & Efficiency & References \\
\hline 1 & $\begin{array}{l}\text { Methyl orange, rhodamine } \mathrm{B} \text {, } \\
\text { methylene blue }\end{array}$ & Bismutite $\left(\mathrm{Bi}_{2} \mathrm{O}_{2} \mathrm{CO}_{3}\right)$ & $\begin{array}{l}\text { For a catalyst dosage of } 0.5 \mathrm{~g} / \mathrm{L} \text {, the adsorption efficiency of } \mathrm{MO} \text {, } \\
\mathrm{RhB} \text { and } \mathrm{MB} \text { were } 2.2 \%, 25.4 \% \text { and } 53.9 \% \text {, respectively }\end{array}$ & [7] \\
\hline 2 & $\begin{array}{l}\text { Heavy metal ions }\left(\mathrm{Zn}^{2+}, \mathrm{Ni}^{2+} \text {, }\right. \\
\left.\qquad \mathrm{Cu}^{2+}, \mathrm{Cr}^{3+} \text { and } \mathrm{Pb}^{2+}\right)\end{array}$ & $\begin{array}{l}\text { Calcium silicate } \\
\text { hydrate }(\mathrm{CSH})\end{array}$ & $\begin{array}{l}\text { Adsorption capability for all heavy metals was greater than } 100 \mathrm{mg} / \\
\mathrm{g}\end{array}$ & {$[12]$} \\
\hline 3 & p-nitrophenol & $\begin{array}{l}\text { Carbon aerogels }(\mathrm{CA}) \\
\text { activated with } \mathrm{KOH}\end{array}$ & $\begin{array}{l}\text { Maximum adsorption capacity of p-nitrophenol onto activated } \\
\text { carbon aerogels was reported } 613.34 \mathrm{mg} / \mathrm{g}\end{array}$ & {$[13]$} \\
\hline 4 & Acetaminophen & Activated carbon & Maximum adsorption capacity $411.0 \mathrm{mg} / \mathrm{g}$ & {$[14]$} \\
\hline 5 & Uranium & Flax fiber (Linen fiber) & $\begin{array}{l}\text { Maximum adsorption of } \mathrm{U} \text { was } 94.50 \% \text { at } \mathrm{pH} 4 \text { and adsorbent dose } \\
\text { of } 1.2 \mathrm{~g}\end{array}$ & {$[15]$} \\
\hline
\end{tabular}

$M B$ methylene blue, $R h B$ rhodamine B, $M O$ methyl orange 
Table 3 Target pollutants and ion exchangers for the removal of pollutants

\begin{tabular}{|c|c|c|c|c|}
\hline $\begin{array}{l}\text { Sr. } \\
\text { no. }\end{array}$ & Target pollutant & Types of ion exchanger used & Efficiency & References \\
\hline 1 & Rhodamine B (RD-B) dye & $\begin{array}{l}\text { Chitosan-gelatin/zirconium(IV) } \\
\text { selenophosphate nanocomposite ion } \\
\text { exchanger }\end{array}$ & $\begin{array}{l}\text { Percentage of dye removal was } 84 \% \text { with ion } \\
\text { exchange capacity of } 2.4 \text { mequiv/g }\end{array}$ & {$[16]$} \\
\hline 2 & Iron-enriched sludge & Ion exchange resins & Iron removal efficiency was found $100 \%$ & {$[17]$} \\
\hline 3 & Olive mill wastewater effluent & Ion exchange resins & $88 \%$ removal of pollutants & {$[18]$} \\
\hline 4 & $\begin{array}{l}\text { Uranium from nuclear industrial } \\
\text { effluent }\end{array}$ & Polymeric ion exchange resin & Uranium removal efficiency was found $98 \%$ & [19] \\
\hline 5 & $\begin{array}{l}\text { Industrial base metal refinery } \\
\text { effluents (Pt, } \mathrm{Pd} \text { and } \mathrm{Rh} \text { metal) }\end{array}$ & Silica-based (poly)amine anion exchanger & $\begin{array}{l}\text { Removal efficiency of Pt and Pd were found } \\
\text { more than } 95 \% \text { and for } \mathrm{Rh} \text { it was } 22 \%\end{array}$ & {$[20]$} \\
\hline
\end{tabular}

Table 4 Membrane type(s) and their efficiency in the removal of pollutants

\begin{tabular}{|c|c|c|c|c|}
\hline $\begin{array}{l}\text { Sr. } \\
\text { no. }\end{array}$ & Target pollutant & Types of membrane used & Efficiency & References \\
\hline 1 & $\begin{array}{l}\text { Atrazine and } \\
\text { carbamazepine }\end{array}$ & Nanofiltration; Filmtec NF90; MWCO = 90-200 Da & $97 \%$ and $91 \%$, respectively & {$[21]$} \\
\hline 2 & Ibuprofen and diclofenac & $\begin{array}{l}\text { Reverse osmosis; Filmtec TW30 MWCO = } 100 \text { Da } \\
\quad 9.5-10.2 \text { 95-99\% [63] }\end{array}$ & $95-99 \%$ & {$[22]$} \\
\hline 3 & Cimetidine & PVDF integrated porous stainless steel $(2 \mu \mathrm{m})$ & $90 \%$ degradation in $4 \mathrm{~h}$ & {$[23]$} \\
\hline 4 & Diphenyl-hydramine & Mixed cellulose ester & $\begin{array}{l}73 \% \text { degradation; } 35 \% \\
\text { mineralization in } 4 \mathrm{~h}\end{array}$ & {$[24]$} \\
\hline 5 & $\begin{array}{l}\text { Direct fast Scarlet Dye } \\
\quad(10 \mathrm{mg} / \mathrm{L})\end{array}$ & $\mathrm{A} 12 \mathrm{O} 3$ ceramic UF $(0.2 \mu \mathrm{m})$ & $99 \%$ in $6 \mathrm{~h}$ & {$[25]$} \\
\hline
\end{tabular}

opportunity to build genetically engineered microorganisms for efficient environmental pollutant removal. Genes isolated from microbial sources have been modified to develop new metabolic pathways. It leads to an enhancement of the processes for the biodegradation of different contaminants. Two pesticide degrading genes $(\operatorname{lin} A$ and $m p d$ ) have been integrated with $E$. coli for the degradation of organochlorine and organophosphates, respectively. This engineered E. coli strain could degrade these pesticides simultaneously [2]. The enzyme, pyrethroid hydrolase, is responsible for the catalytic degradation of fenpropathrin and it was found that $P y t H$ gene (isolated from Sphingobium sp. JZ-2) is responsible for the synthesis of pyrethroid hydrolase. Later, this $p y t H$ was manipulated in Sphingobium sp. BA3 to create a more biodegradable recombinant strain. [6].

Azoreductase or azobenzene reductase is capable of removing azo dyes discharged as effluents in textile industries. Azoreductase was isolated from several different microorganisms like Enterobacter agglomerans, Enterococcus faecalis and Xenophilus azovogarls KF46F. Several scientists have subsequently identified $f d h$ (responsible for the synthesis of dehydrogenase) and azoA (responsible for the synthesis of azoreductase) genes isolated from Mycobacterium vaccae and Enterococcus sp. L2, respectively. These genes are responsible for decolorization of synthetic dye present in industrial waste [6].

The alkane monooxygenase coding gene (alkB) has been manipulated to the non-alkane degrading strain of Streptomyces coelicol M145 strain that could improve the performance to degrade hydrocarbons. Aromatic hydrocarbon could be metabolized by a strain of Pseudomonas putida BNF1. Later the responsible gene (Xyle) and coded enzyme (catechol 2,3-dioxygenase) were characterized. This particular gene (Xyle) was cloned from Pseudomonas putida BNF1 plasmid DNA and inserted into Acinetobacter sp to increase the degradation of alkanes [6].

\section{Microbial Electrochemical Technologies: A Sustainable Solution}

Microbial electrochemical technology (MET) is an emerging area applied in the field of interdisciplinary subjects with a biological intervention that has been used in the last decade. Broadly, it is applied in the field of microbial fuel cell (MFC) technology, bioelectrochemical treatment (BET) system, microbial electrolysis cell (MEC) 
and microbial electrosynthesis system (MES) [26-29]. Many scientists have focused on the treatment of industrial effluents along with the production of energy with the applications of low-cost electrodes and indigenous microorganisms to develop an environmentally sustainable process [30]. A summary of pollutants and their removal through microbial MFC technology is given in Table 5.

\section{Knowledge Gaps, Challenges and Perspectives}

One of the easiest ways to clean up the contaminated region is an environmentally friendly and low-cost bioremediation solution. In addition, the rate of degradation of the pollutant, reaction model, pathways of degradation, mechanisms of degradation and physiological key factors accountable for the degradation should be considered. In many cases, the side products generated by the degradation process were found to be more persistent and dangerous than the original pollutants. This is a major challenge and thrust area to be addressed by the researchers.
The degradation of organic contaminants is promoted by some major catabolic genes such as phosphotriesterases, biphenyl dioxygenase and oxygenase. However, with the advent of biotechnological advancements various "omics" applications (metatranscriptomics, metagenomics and metabolomics) are being considered to develop a reliable method for determination, detection and removal of pollutants from the environment. In addition, development in microbial electrochemical technologies, nanomaterialbased remediation and constructed wetlands augment the removal of pollutants from the environment.

The concept of "nanobioremediation" has just emerged, using nanoparticles synthesized by bacteria, algae, fungi and specific plants under controlled conditions to eliminate organic contaminants from soil and wastewater. Application of nanotechnology for remediation of pollutants can be taken into consideration due to various advantages like (1) giving rise to sustainable products, (2) remediation of hazardous substances and (3) development of biosensors to monitor the environmental pollution.

A new technique with advanced tools such as genetic engineering, metabolic engineering, bioelectronics, protein

Table 5 Microbial fuel cell (MFC) in the removal of selected pollutants

\begin{tabular}{|c|c|c|c|c|}
\hline $\begin{array}{l}\text { Sr. } \\
\text { no }\end{array}$ & Target pollutant & MFC specification & Removal efficiency & References \\
\hline 1 & Total petroleum hydrocarbon & $\begin{array}{l}\text { Single-chambered } \\
(6 \mathrm{~cm} \times 6 \mathrm{~cm} \times 6 \mathrm{~cm}) \\
\text { Anode: Carbon mesh } \\
\text { Cathode: Activated carbon }\end{array}$ & $\begin{array}{l}\text { Closed circuit: } \\
\quad 77 \pm 2.4 \% \\
\text { Open circuit: } 14.8 \%\end{array}$ & [26] \\
\hline 2 & $\begin{array}{l}\text { Petroleum hydrocarbon- } \\
\text { contaminated soil }\end{array}$ & $\begin{array}{l}\text { Single-chambered } \\
(6 \mathrm{~cm} \times 6 \mathrm{~cm} \times 20 \mathrm{~cm}) \\
\text { Anode: Graphite rod } \\
\text { Cathode: Activated carbon }\end{array}$ & $\begin{array}{l}\text { Closed circuit: } \\
\text { TPHs } 30 \pm 1 \% \\
\text { PAHs } 33-45 \% \\
\text { Open circuit: } \\
\text { TPHs } 11 \% \\
\text { PAHs } 22 \pm 4 \%\end{array}$ & [27] \\
\hline 3 & $\begin{array}{l}\text { Petroleum hydrocarbon- } \\
\text { contaminated soil }\end{array}$ & $\begin{array}{l}\text { Dual-chambered } \\
(0.25 \mathrm{~L}) \\
\text { Anode: Carbon cloth } \\
\text { Cathode: Carbon cloth (potassium ferricyanide severed as } \\
\text { cathode solution) }\end{array}$ & & [28] \\
\hline 4 & $\begin{array}{l}\text { Diesel oil-contaminated soil } \\
\text { sample }\end{array}$ & $\begin{array}{l}\text { Column-type chamber } \\
(40 \mathrm{~cm} \times 5.5 \mathrm{~cm} \times 20 \mathrm{~cm}) \\
\text { Anode: Carbon felt anode } \\
\text { Cathode: Carbon cloth with activated carbon catalyst }\end{array}$ & $\begin{array}{l}\text { Closed circuit: } 41 \% \\
\text { Open circuit: } 34 \%\end{array}$ & [29] \\
\hline 5 & Isoproturon (IPU) & $\begin{array}{l}\text { Single-chambered } \\
(0.25 \mathrm{~L}) \\
\text { Anode: Carbon mesh } \\
\text { Cathode: Activated carbon }\end{array}$ & $\begin{array}{l}\text { Closed circuit: } 21.3 \% \\
\text { Open circuit: } 1 \%\end{array}$ & {$[30]$} \\
\hline
\end{tabular}


engineering, genomics and proteomics, nanobiotechnology and bioreactor technology has gained momentum in research and development to improve the process of bioremediation. A new technique such as "biofilm system" has also been developed to remedy the wastewater recalcitrant pollutants. The application of the "biofilm framework" for bioremediation can be a future area for working on this topic. Scientific research on environmental biotechnology has recently become such a research hot spot on the adsorption of pollutants by the application of biochar. Generally, biochar is a very well-developed capillary framework enriched with oxygen-containing monomers along with some minerals.

This can be inferred that researchers' focus has been attained by biosensors derived from microorganisms due to their high sensitivity to target pollutants and noninvasive design. Degradation of contaminants from the environment through adding microorganisms is an emerging technology; however, various genetic approaches to improve metabolic pathways, growth conditions and development of enzymes are highly beneficial in meeting demand.

\section{Conclusions}

Effluents from various sources pose a big threat to the world of pollution. There are plenty of POPs that are extremely dangerous for us all. These have created various problems for health and the environment. They are silent killers due to their bioaccumulation in adipose tissues and long persistence natures. Diabetes, obesity, endocrine disorders, cancer, cardiovascular, reproductive and other health issues are various diseases associated with POPs. Most people do not know about POPs lethal effects. To create awareness among farmers and other interested persons, organizing seminars and conferences at the village level is necessary. Manufacture and use of POPs globally should be strictly prohibited. However, there is a great need to implement quick, reliable and affordable methods of remediation to eliminate POPs from the environment.

Acknowledgements Bishwambhar Mishra acknowledges Chaitanya Bharathi Institute of Technology, Hyderabad, India, for providing good infrastructure and smart digital library facilities.

\section{Compliance with Ethical Standards}

Conflict of interest The authors declare that they have no conflict of interest.

\section{References}

1. Paździor K, Bilińska L, Ledakowicz S (2019) A review of the existing and emerging technologies in the combination of AOPs and biological processes in industrial textile wastewater treatment. Chem Eng J 376:120597. https://doi.org/10.1016/ j.cej.2018.12.057

2. Varjani SJ, Srivastava VK, Raveendran S, Thakur IS, Gnansounou E (2018) Culture based approaches, dependent and independent, for microbial community fractions in petroleum oil reservoirs. Indian J Exp Biol 56:444-450. https://doi.org/ 10.1016/j.biortech.2017.08.02

3. Zaiming C, Xin X, Baoshan X, Baoliang C (2019) pH-dependent sorption of sulfonamide antibiotics onto biochars: sorption mechanisms and modelling. Environ Pollut 248:48-56. https://doi.org/10.1016/j.envpol.2019.01.087

4. Wu Q, Wang H, Yi C (2018) Preparation of photo-Fenton heterogeneous catalyst (Fe-TS-1 zeolite) and its application in typical azo dye decoloration. J Photochem Photobiol A Chem 356:138-149. https://doi.org/10.1016/j.jphotochem.2017.12.041

5. Varjani SJ (2017) Microbial degradation of petroleum hydrocarbons. Bioresour Technol 223:277-286. https://doi.org/ 10.1016/j.biortech.2016.10.037

6. Mishra B, Varjani S, Iragavarapu GP, Ngo HH, Guo W, Vishal B (2019) Microbial fingerprinting of potential biodegrading organisms. Curr Pollut Rep 5:181-197. https://doi.org/ 10.1007/s40726-019-00116-5

7. Xu R, Su M, Liu Y, Chen Z, Ji C, Yang M, Chang X, Chen D (2020) Comparative study on the removal of different-type organic pollutants on hierarchical tetragonal bismutite microspheres: adsorption, degradation and mechanism. J Clean Prod 242:118366. https://doi.org/10.1016/j.jclepro.2019.118366

8. Sun C, Yang S-T, Gao Z, Yang S, Yilihamu A, Ma Q, Zhao R-S, Xue $\mathrm{F}$ (2019) $\mathrm{Fe}_{3} \mathrm{O}_{4} / \mathrm{TiO}_{2} /$ reduced graphene oxide composites as highly efficient Fenton-like catalyst for the decoloration of methylene blue. Mater Chem Phys 223:751-757. https://doi.org/ 10.1016/j.matchemphys.2018.11.056

9. Zhang X, Lin X, He M, Li H, Wang W, Yang ST (2016) Carbon coated titanium electrode for the electrolytic decoloration of methylene blue. J Water Process Eng 13:183-188. https://doi.org/ 10.1016/j.jwpe.2016.09.004

10. Wang T, Qu G, Ren J, Sun Q, Liang D, Hu S (2016) Organic acids enhanced decoloration of azo dye in gas phase surface discharge plasma system. J Hazard Mater 302:65-71. https://doi.org/10.1016/j.jhazmat.2015.09.051

11. Zhang G, Okajima I, Sako T (2016) Decomposition and decoloration of dyeing wastewater by hydrothermal oxidation. J Supercrit Fluids 112:136-142. https://doi.org/10.1016/j.supflu. 2015.10.014

12. Shao N, Li S, Yan F, Su Y, Liu F, Zhang Z (2020) An all-in-one strategy for the adsorption of heavy metal ions and photodegradation of organic pollutants using steel slag-derived calcium silicate hydrate. J Hazard Mater 382:121120. https://doi.org/ 10.1016/j.jhazmat.2019.121120

13. Li K, Zhou M, Liang L, Jiang L, Wang W (2019) Ultrahighsurface-area activated carbon aerogels derived from glucose for high-performance organic pollutants adsorption. J Colloid Interface Sci 546:333-343. https://doi.org/10.1016/j.jcis.2019.03.076

14. Limaa DR, Hosseini-Bandegharaei A, Thued PS, Limaa EC, de Albuquerquea YRT, dos Reisa GS, Umpierresd CS, Diasa SLP, Trang HN (2019) Efficient acetaminophen removal from water and hospital effluents treatment by activated carbons derived from Brazil nutshells. Colloids Surf A Physicochem Eng Asp 583:123966. https://doi.org/10.1016/j.colsurfa.2019.123966

15. Abutaleb A, Tayeb AM, Mahmoud MA, Daher AM, Desouky OA, Yahya Bakather O, Farouq R (2019) Removal and recovery of U(VI) from aqueous effluents by flax fiber: adsorption, desorption and batch adsorber proposal. J Adv Res. https://doi.org/10.1016/j.jare.2019.10.011 
16. Kaur K, Jindal R (2018) Synergistic effect of organic-inorganic hybrid nanocomposite ion exchanger on photocatalytic degradation of Rhodamine-B dye and heavy metal ion removal from industrial effluents. J Environ Chem Eng 6:7091-7101. https://doi.org/10.1016/j.jece.2018.09.065

17. Martins PJM, Reis PM, Martins RC, Gando-Ferreira LM, QuintaFerreira RM (2017) Iron recovery from the Fenton's treatment of winery effluent using an ion-exchange resin. J Mol Liq 242:505-511. https://doi.org/10.1016/j.molliq.2017.07.041

18. Víctor-Ortega MD, Ochando-Pulido JM, Airado-Rodríguez D, Martínez-Ferez A (2016) Comparison between different ion exchange resins combinations for final treatment of olive mill effluent. Sep Purif Technol 158:374-382. https://doi.org/10.1016/ j.seppur.2015.12.041

19. Ladeira ACQ, Morais CA (2005) Uranium recovery from industrial effluent by ion exchange-column experiments. Miner Eng 18:1337-1340. https://doi.org/10.1016/j.mineng.2005.06.012

20. Kramer J, Driessen WL, Koch KR, Reedijk J (2002) Highly selective extraction of platinum group metals with silica-based (poly) amine ion exchangers applied to industrial metal refinery effluents. Hydrometallurgy 64:59-68. https://doi.org/10.1016/ s0304-386x(02)00010-5

21. Yangali-Quintanilla V, Maeng SK, Fujioka T, Kennedy M, Li Z, Amy G (2011) Nanofiltration vs. reverse osmosis for the removal of emerging organic contaminants in water reuse. Desalin Water Treat 34:50-56. https://doi.org/10.5004/dwt.2011.2860

22. Agata EL, Santiago GR, José MQA (2019) Removal of emerging contaminants from wastewater using reverse osmosis for its subsequent reuse: pilot plant. J Water Process Eng. https://doi.org/10.1016/j.jwpe.2019.100800

23. Ramasundaram S, Yoo HN, Song KG, Lee J, Choi KJ, Hong SW (2013) Titanium dioxide nanofibers integrated stainless steel filter for photocatalytic degradation of pharmaceutical compounds. J Hazardrous Mater 258-259:124-132. https://doi.org/10.1016/ j.jhazmat.2013.04.047
24. Pastrana-Martinez LM, Morales-Torres S, Figueiredo JL, Faria JL, Silva AMT (2015) Graphene oxide-based ultrafiltration membranes for photocatalytic degradation of organic pollutants in salty water. Water Res 77:179-190. https://doi.org/10.1016/ j.watres.2015.03.014

25. Fischer K, Grimm M, Meyers J, Dietrich C, Gläser R, Schulze A (2015) Photoactive microfiltration membranes via directed synthesis of $\mathrm{TiO}_{2}$ nanoparticles on the polymer surface for removal of drugs from water. J Membr Sci 478:49-57. https://doi.org/ 10.1016/j.memsci.2015.01.009

26. Li X, Zhao Q, Wang X, Li Y, Zhou Q (2017) Surfactants selectively reallocated the bacterial distribution in soil bioelectrochemical remediation of petroleum hydrocarbons. J Hazard Mater 344:23-32. https://doi.org/10.1016/j.jhazmat.2017.09.050

27. Li X, Wang X, Zhao Q, Wan L, Li Y, Zhou Q (2016) Carbon fiber enhanced bioelectricity generation in soil microbial fuel cells. Biosens Bioelectron 85:135-141. https://doi.org/10.1016/ j.bios.2016.05.001

28. Zhou L, Deng D, Zhang D, Chen Q, Kang J, Fan N, Liu Y (2016) Microbial electricity generation and isolation of exoelectrogenic bacteria based on petroleum hydrocarbon-contaminated soil. Electroanalysis 28:1510-1516. https://doi.org/10.1002/elan.2015 01052

29. Li X, Wang X, Wan L, Zhang Y, Li N, Li D, Zhou Q (2016) Enhanced biodegradation of aged petroleum hydrocarbons in soils by glucose addition in microbial fuel cells. J Chem Technol Biotechnol 91:267-275. https://doi.org/10.1002/jctb.4660

30. Mao D, Lu L, Revil A, Zuo Y, Hinton J, Ren ZJ (2016) Geophysical monitoring of hydrocarbon-contaminated soils remediated with a bioelectrochemical system. Environ Sci Technol 50:8205-8213. https://doi.org/10.1021/acs.est.6b00535

Publisher's Note Springer Nature remains neutral with regard to jurisdictional claims in published maps and institutional affiliations. 